\title{
The rise of human dignity
}

\section{Dietmar von der Pfordten}

The phenomenon and concept of human dignity shows four decisive peculiarities: (1) A late appearance as concept in our ordinary conceptual scheme. (2) A late appearance as concept in practical philosophy. (3) A late appearance as fundamental human right in charters, constitutions and human rights declarations. (4) But it finally rose to be the lead right in some of these charters, constitutions and declarations, e.g. the United Nations Charter from 1945, the German "Grundgesetz" from 1949 and the Charter of Fundamental Rights of the EU from 2000.

The following reflections on human dignity are divided into two sections: first a historical reconstruction and second a systematic suggestion how one should understand the concept, especially in the light of these peculiarities.

\section{Historical Reconstruction}

\section{Antiquity and Middle Ages}

In Greek antiquity, there was no concept of human dignity or a terminological equivalent. So we face a late significance of the concept in antique philosophy. Cicero was the first to mention "dignitas" in De Officiis in $44 \mathrm{~b}$. Chr.:" "If we want to consider that a superior position and dignity is in our nature, we realize how awful it is to let oneself drift along and live pampered and softy; and how it is on the other side honorable to live economical, abstinent, stern and sober. (Atque etiam, si considerare volemus, quae sit in natura nostra excellentia et dignitas, intellegemus, quam sit turpe diffluere luxuria et delicate ac molliter vivere, quamque honestum parce, continenter, severe, sobrie)." Cicero used the concept probably as a translation of the stoic "axioma" from Panaitios from Rhodos, which means honor, respect, valuation, volition.

Already in this quotation we find, albeit not yet distinguished, two possibilities of the understanding of human dignity: dignity as (1) unchangeable, essential inner worth of men, (2) a contingent, external property like a) status/rank/office, b) behavior, c) aesthetic expression, which leads at best to an inter-subjective understanding of human dignity.

Subsequently human dignity is mentioned in the writings of Christian thinkers. In these writings, the accent lies on the first understanding, the understanding of unchangeable inner worth independent of the social position and with respect to the idea that man is created by God, an image of God and has reason. Thomas Aquinas writes e. g. in his Summa theologica from $1265 \mathrm{ff} . .^{2}$ “.... when he commits a sin, man leaves the

${ }^{1}$ Cicero, De Officiis, I, 105 f.,

2 Thomas Aquinas, Summa theologica II-H, qu, 64, 2 ad 3 . See also I, qu 29 a 3. 
order of reason and therefore breaks away from the dignity of man, in so far as man is free by nature and exists because of himself... (... homo peccando ab ordine rationis recedit: et ideo decidit a dignitate humana, prout scilicet homo est naturaliter liber et propter seipsum existens...)". In these and other citations dignitas is understood as an essential, unchangeable quality. In the ethics of Thomas Aquinas the concept plays a certain role, but is not fundamental. ${ }^{3}$

If dignity is understood as an essential, unchangeable quality of man then we have to ask what the source of this quality is. Again, there are two possible answers: The source can be internal (autonomous) or external (heteronomous). For Cicero and the Christian thinkers the answer is clear: The source of human dignity is external. They derive the unchangeable inner worth of human dignity from an external legitimation, an external source of value. Cicero roots it in the stoic logos as law of the world and Christian thinkers root it in God's creation of the world, the creation of man as God's image and the divine hierarchy of leges (lex aeterna, lex naturalis, lex divina, lex humana). Therefore, the external source of human dignity can be characterized as heteronomous, not autonomous.

\section{Renaissance}

In the Renaissance we find the term dignitas e. g. in Bartolomeo Fazio's De excellentia et praestantia hominis (1447) and in Giannozzo Manetti's De dignitate et excellentia hominis (1452), but it is not very central. These tracts about the conditio humana are directed against the medieval literature of misericordia, especially against Pope Innocent III's: De miseria humanae conditionis (1194/95). They are attacking the idea that man is bad from nature because of the original sin. They want to show that man is good because he is created as image of God with reason etc. In Renaissance we find a positive, optimistic notion of man. The Renaissance has set the person at the highest position that is at the centre of its anthropology without relying on religious foundations. However, dignity is not characterized as a special quality and no ethics with lasting influence was developed on this basis.

Some have thought that Pico della Mirandola is an exception. But his Oratio quaedam elegantissima from 1486 was only long after his death famously titled De hominis dignitate by the editor Jacob Wimpfling in his Strassburg edition from 1504, perhaps with the aim to show that this tract is in line with the Christian doctrine. Nonetheless, "dignitas" is not mentioned in the text. Pico puts the human being on top of a hierarchy, able to perfect himself. So the human being is not fixed and predetermined. He can sink to be like a beast and rise to be like a God. But dignity is not mentioned as a special quality. One can assume that this characterization is avoided consciously, because Pico does not propose a fixation of the human character with reference to man's creation by God, his God-like image or his reason.

3 Cf. J. Lenz, 'Die Personwürde des Menschen bei Thomas von Aquin', Philosophisches Jahrbuch 49 (1936), pp. 139-166. 
What is the reason that these early Renaissance thinkers, like Pico, did not use the term "dignity" and that they, like Manetti, did not put it in a central position of their argumentation? I think they wanted to avoid the religious loaded, heteronomous concept of dignity, which was coined by the Christian thinkers. In Renaissance, man is thought as autonomous beings, for example by Pico. Against this background, the religious and heteronomous understanding of dignity does not fit very well.

\section{Early Modernity and Kant}

Dignity does not play a role at all in the tracts of the major new thinkers of early modernity - that is of the $17^{\text {th }}$ century - like Grotius, Descartes, Hobbes, Locke or Spinoza. The reason was probably the same as for the philosophers of the Renaissance: they wanted to avoid the religiously loaded, heteronomous concept of dignity coined by the Christian thinkers in late antiquity and the middle ages.

Only Pufendorf, who referred much more than the Western thinkers - that is English, French and Dutch ones - to the tradition of Aristotle and Christian theologians, mentions "dignity", albeit briefly. In De jure naturae et gentium libri octo from 1684 he writes: ${ }^{4}$ "The dignity of man above all animals is revealed especially by the fact that he is equipped with a noble soul, which is able to understand and differentiate the things with extraordinary insight, to attain or dismiss them with an outstanding movability. [...] This faculty of the human soul, which contains an image of higher insight, is result of reason (Ex hoc igitur dignitas hominis prae brutis maxime elucet, quod iste nobililissima praeditus est anima, quae \& insigni lumine circa cognoscendas \& dijudicandas res, \& exquistia nobilitate circa easdem adpetendas aut resiciendas pollet. [...] Illa porro animae humanae potentia, quae instar aliquod luminis gerit, intellectus nomine venit...).“ This is - mentioning the soul as image of God - still a religious, external and therefore heteronomous concept of dignity, not an internal, autonomous one. There was no significant reception of this concept of Pufendorf or of the concept of human dignity in general by other natural-law-theorists of the 17 th or $18^{\text {th }}$ century, like Thomasius, Wolff, Achenwall and Hufeland.

Only Kant has finally stressed the dignity of man in his Groundwork of the Metaphysics of Morals (Grundlegung zur Metaphysik der Sitten) from 1785 by giving it a new autonomous and therefore non-religious understanding. ${ }^{5}$ This has prompted some interpreters to assign dignity a central role in Kantian ethics. ${ }^{6}$ This, however, should be

${ }^{4}$ Samuel v. Pufendorf, De jure naturae et gentium libri octo, I, 3, 1.

5 Immanuel Kant, Groundwork of the Metaphysics of Morals/Grundlegung zur Metaphysik der Sitten, Academy-Edition, Vol. IV, Berlin 1903/11, pp. 434 f. See for an interpretation of the notion of human dignity in Kant, Dietmar von der Pfordten, 'On the Dignity of Man in Kant', in: Philosophy 84 (2009), pp. 371-391. German: 'Zur Würde des Menschen bei Kant', in: Recht und Sittlichkeit bei Kant, Jahrbuch für Recht und Ethik, ed. Sharon Byrd et. al. 2006, pp. 501-517.

6 Neil Roughley, article 'Würde', in: Jürgen Mittelstraß (ed.), Enzyklopädie Philosophie und Wissenschaftstheorie vol. 4, Sp-Z, Stuttgart/Weimar 1996, pp. 784-787, p. 784; Josef Santeler, Die Grundlegung der Menschenwürde bei I. Kant, Innsbruck 1962. 
stated with caution for a number of reasons. ${ }^{7}$ In the more extensive elaboration of his ethics in the Critique of Practical Reason (Kritik der praktischen Vernunft) from 1788, which is particularly important in the overall context of his critical project, the term does not occupy any significant position and is mentioned only twice en passant. In the second part of the Metaphysics of Morals (Metapysik der Sitten) from 1798, it only appears again in the Doctrine of Virtue (Metaphysische Anfangsgründe der Tugendlehre) but not in the Doctrine of Right (Metaphysische Anfangsgründe der Rechtslehre) In the Groundwork of the Metaphysics of Morals, the term dignity appears relatively late, namely in the course of explaining the third formula of the categorical imperative. Yet the concept of "human dignity" is often, and mostly without further discussion, associated $^{8}$ with the second formula of the categorical imperative: "So act that you use humanity, whether in your own person or in the person of any other, always at the same time as an end, never merely as a means". ${ }^{9}$ This is the case with the widely accepted interpretation $^{10}$ of the Federal Constitutional Court of Article 1 Paragraph 1 of the German Constitution, the prohibition of violating human dignity ("object formula"). ${ }^{11}$ However, in the course of developing the second formula of the categorical imperative, Kant does not refer to dignity at all. ${ }^{12}$ This cannot be a coincidence. The second formula of the categorical imperative demands the recognition of others and of the agent himself as an end. However, this demand is formulated from the perspective of the individual agent. Only in the context of the kingdom of ends the perspective of a detached, godlike observer is taken, who is explicitly not an addressee of the categorical imperative. Only in this detached, godlike perspective, which Kant associates with the

${ }^{7}$ Cf. for more details: Dietmar von der Pfordten, 'On the Dignity of Man in Kant', in: Philosophy 84 (2009), pp. 371-391.

8 Beat Sitter-Liver, 'Würde der Kreatur: Grundlegung, Bedeutung und Funktion eines neuen Verfassungsprinzips', in: Julian Nida-Rümelin/Dietmar von der Pfordten, Ökologische Ethik und Rechtstheorie, 2. ed. Baden-Baden 2002, pp. 355-364, p. 359. Norbert Hoerster, 'Zur Bedeutung des Prinzips der Menschenwürde', Juristische Schulung 23 (1983), pp. 93-96, p. 93 equals without further reference the second formula with means in itself.

${ }^{9}$ Immanuel Kant, Groundwork of the Metaphysics of Morals/Grundlegung zur Metaphysik der Sitten, p. 429.

10 The formula goes back to Günter Dürig, 'Der Grundrechtssatz von der Menschenwürde', Archiv des öffentlichen Rechts 81/2 (1956), pp. 117-157, p. 128: "It is a violation of human dignity as such if a human being is treated like an object by a legal proceeding."; id., in: Theodor Maunz/Günter Dürig (eds.), Grundgesetz. Kommentar, München 2001, Art. 1, Rn 28. Cf. Tatjana Geddert-Steinacher, Menschenwürde als Verfassungsbegriff. Aspekte der Rechtsprechung des Bundesverfassungsgerichts zu Art. 1 Abs. 1 Grundgesetz, Berlin 1990, p. $31 \mathrm{ff}$.

11 BVerfGE 5, 85 (204); 7, 198 (205); 27, 1 (6): "It is against human dignity to make a human being to a mere object of the state.”; 28, 386 (391); 45, 187 (228); 50, 166 (175); 56, 37 (43). Cf. Christian Starck, 'Menschenwürde als Verfassungsgarantie im modernen Staat', Juristenzeitung 36 (1981), pp. 457-464.

12 Therefore incorrect: Philipp Balzer/Klaus P. Rippe/Peter Schaber, Menschenwürde vs. Würde der Kreatur: Begriffsbestimmung, Gentechnik, Ethikkommissionen, S. 23. The quoted page BA 79, 80 does not mention the second formula but only the rest of the third formula and a summary of all formulas. In the context of the second formula at $\mathrm{BA}, 66 \mathrm{f}$ dignity is not mentioned. 
category of totality but not of plurality, which is associated with the second formula, ${ }^{13}$ Kant mentions the dignity of man. ${ }^{14}$

What is the difference between the state of being an end in oneself and the dignity of man? Kant defines "dignity" as the quality of a rational being "who obeys no law other than that which he simultaneously gives himself." 15 Accordingly, it is a crucial condition that every being capable of dignity is himself the author of his own ethical restrictions. This is not yet necessarily established by the second formula of the categorical imperative, that is, the "end-in-oneself-ness" formula, for the recognition of others as ends in themselves only requires that the agent does not use others as mere means. And this does not say anything about the reason why he must not use others as mere means, that is, it does not make explicit on which foundation the obligation to recognize the independent ends of others rests. For it is not explicitly set forth that the obligation to recognize the ends of others and of oneself necessarily derives from the other and oneself as possessors of these ends. After all, one might also conceive of an ultimate obligation posed, say, by divine law, that is a heteronomous source. The second formula of the categorical imperative, the formula of ends-in-themselves (Selbstzweckformel), only states the necessity to ethically consider human beings for their own sake.

Only when Kant defines the human being as self-legislating and as member of the legislating kingdom of the ends of all rational beings, that is as an autonomous being, does he exclude an ultimate relativization of the "end-in-himself-ness" of persons to other normative sources, that is, to heteronomous sources lying beyond the affected individual in question, e.g. in God. Such alternative, heteronomous sources are excluded in two ways: First, the classification of individual human beings in the legislating kingdom of ends makes the idea of the completeness of the end-determining entities possible. The kingdom of ends represents a "whole of all ends." ${ }^{, 16}$ Second, as mentioned before, God, as well as other possibly existing rational beings, is integrated into the kingdom of ends. The formula of ends in themselves is restricted to humanity, at least in its explicit formulation; by contrast, the "kingdom of ends" consists, according to Kant, not only of "members" - which, though universally legislating, are also subject to

13 Immanuel Kant, Groundwork of the Metaphysics of Morals/Grundlegung zur Metaphysik der Sitten, p. 436

14 However, the identification of dignity and means in itself occurs 14 years later in the Metaphysics of Morals: Immanuel Kant, Metaphysics of Morals/Die Metapysik der Sitten, Academy-Edition, Vol. VI, Berlin 1907/1914, p. 462: "Humanity itself is a dignity; for a human being cannot be used merely as a means by any human being (either by others or even by himself) but must always be used at the same time as an end. It is just in this that his dignity (personality) consists, by which he raises himself above all other beings in the world that are not human beings and yet can be used, and so over all things." The bracketed notion "personality" after the notion dignity shows that it is here used differently than before in the Foundations. Norbert Hoerster, Zur Bedeutung des Prinzips der Menschenwürde, p. 96, tellingly omits the bracketed notion (personality).

15 Immanuel Kant, Groundwork of the Metaphysics of Morals/Grundlegung zur Metaphysik der Sitten, p. 434.

16 Ibid, p. 433. 
these laws - but also includes a legislating "head" which is not subjected to any law. ${ }^{17}$ While Christian tradition rooted human dignity in the heteronomous dependency of human beings on God $^{18}$ Kant now conversely construes the dignity of man as partial equality of human beings and God as the moral legislator in a common legislating kingdom of ends. This idea of autonomous self-legislation and of the legislating kingdom of ends leads to the postulate that only rational beings can be legislating in the kingdom of ends. Since animals are not rational in this substantial sense, they cannot be awarded the status of legislating members in the kingdom of ends. According to Kant, they cannot claim internal, morally relevant dignity like human beings. For Kant there are no direct ethical obligations to animals, only obligations to other humans with regard to animals. ${ }^{19}$

The explicatory difference between the quality of "end-in-oneself-ness" and selflegislation as precondition of dignity becomes apparent in various places. Kant writes: "but that which constitutes the condition under which alone something can be an end in itself has not merely a relative worth, that is, a price, but an inner worth, that is, dignity." ${ }^{20}$ Dignity is characterized here as an explication of the "condition" of "end-inoneself-ness," not as a direct explication of "end-in-oneself-ness." Elsewhere Kant writes: "Autonomy is therefore the ground of the dignity of human nature and of every rational nature." 21

Thus, self-legislation, the autonomy of man, is the central source of normativity in Kantian ethics. In the context of a kingdom of ends this self-legislation constitutes the dignity of man. It leads in conflict situations of individual ethics to the obligation to respect the "end-in himself-ness" of the other or of oneself as part of humanity. Among all living beings only human beings are to be respected as end in themselves and only human beings have dignity. However, dignity is not the ultimate source of ethical obligation. The ultimate reason for ethical obligation rather lies in the human capacity of self-legislation, in the "fact of reason" 22 or in the "moral law within me" ${ }^{23}$ Dignity as absolute "inner worth" is an idealistic-analytic specification of this ultimate source of ethical obligation, namely, the idea of the legislating status of the human being in the kingdom of ends. By contrast, the obligation to respect the "end-in-oneself-ness" in

17 Ibid.

18 For a modern version of this view see Josef Santeler, Die Grundlegung der Menschenwürde bei I. Kant, p. 282.

19 Immanuel Kant, Metaphysics of Morals/Die Metaphysik der Sitten, p. 442. Cf. Dietmar von der Pfordten, Ökologische Ethik. Zur Rechtfertigung menschlichen Verhaltens gegenüber der Natur, pp. 42 ff.

20 Immanuel Kant, Groundwork of the Metaphysics of Morals/Grundlegung zur Metaphysik der Sitten, p. 435.

${ }^{21}$ Immanuel Kant, Groundwork of the Metaphysics of Morals/Grundlegung zur Metaphysik der Sitten, p. 436.

22 Immanuel Kant, Critique of Practical Reason/Kritik der praktischen Vernunft, Academy-Edition, Vol. V, Berlin 1908/13, p. 31.

23 Ibid p. 161. 
accordance with the second formula of the categorical imperative is an explication of this ultimate reason from the perspective of the direction of the act in the more specific conflict case. However, this specific Kantian view of the basis of ethical obligation is problematic. ${ }^{24}$ The premise of a moral law inherent to human beings and of their autonomy in a strong sense is metaphysical and hence questionable.

After Kant the concept of human dignity played neither in Hegel nor in Fichte or Schelling a central or only elevated role. It is only rarely used en passant.

Fichte mentioned it, e. g. in Das System der Sittenlehre from 1798, in a clearly religious, that is heteronomous sense: ${ }^{25}$ "The dignity of each human being depends especially on that he directs his business on a reasonable end or, what means the same, the end of God and that he could say to himself: It is God's will what I am doing. (Die Würde jedes Menschen, seine Selbstachtung und mit ihr seine Moralität hängt vorzüglich davon ab, dass er sein Geschäft auf den Vernunftzweck, oder, was dasselbe heißt, auf den Zweck Gottes mit dem Menschen beziehen, und sich sagen könne: es ist Gottes Wille, was ich tue.)." And in the afterword to his lectures with the title Über die Würde des Menschen from 1794 we do not find the term mentioned. The main conclusion of the text is the following: ${ }^{26}$ "All individuals are enclosed in the one great unity of the pure spirit. (Alle Individuen sind in der einen großen Einheit des reinen Geistes eingeschlossen.)."

In Hegel's Grundlinien der Philosophy des Rechts from 1821 one does not find a significant mentioning, only occasionally the phrase "sittlicher Wert und Würde". In the Vorlesungen über die Philosophie der Religion from 1832, Hegel writes concerning natural religion: ${ }^{27}$ "But to the contrary, man has total worthlessness here [i.e. in natural religion], because man does not have dignity through that what he is as immediate volition, but only insofar as he knows from an in-and-for-itself-being, a substance and submits his natural will to him. (Aber im Gegenteil, vollkommenen Unwert hat hier [in der Naturreligion, DvdP] der Mensch - denn Würde hat der Mensch nicht dadurch, was er als unmittelbarer Wille ist, sondern nur indem er von einem Anundfürsichseienden, einem Substantiellen weiß und diesem seinen natürlichen Willen unterwirft und gemäß macht.). “

In Schelling we find only two citations in the edited volumes of the academyedition. In the Allgemeine Übersicht der neuesten philosophischen Literatur from 1797 and in the Philosophisches Journal he writes: ${ }^{28}$ "dignity of human nature (Würde der

24 For further criticism see Dietmar von der Pfordten, Ökologische Ethik. Zur Rechtfertigung menschlichen Verhaltens gegenüber der Natur, Reinbek 1996, pp. 42 ff.

25 Johann Gottlieb Fichte, Das System der Sittenlehre nach den Prinzipien der Wissenschaftslehre, p. 362.

26 Johann Gottlieb Fichte, Über die Würde des Menschen, p. 416.

27 Georg Wilhelm Friedrich Hegel, Vorlesungen über die Philosophie der Religion, Werke 16+17, Frankfurt/M. 1986, p. 301.

${ }^{28}$ Friedrich Wilhelm Joseph Schelling, 'Allgemeine Übersicht der neuesten philosophischen Literatur’, Philosophisches Journal, Akademieausgabe, Vol. 4, Stuttgart 1988, p. $65,99$. 
menschlichen Natur)" and "dignity of human spirit (Würde des menschlichen Geistes)."

The decrease of the importance of the concept after Kant shows that Kant's successors did not regard the Kantian use of the concept as being important, especially his autonomous understanding. Instead we face a revival of the heteronomous understanding of the concept. This can perhaps explain why the concept of human dignity could not influence the human-rights movement in the late $18^{\text {th }}$ and $19^{\text {th }}$ century at all. This progressive movement had obviously no reason to return to a heteronomously and religiously understood concept of the Middle Ages.

\section{Systematic Suggestions}

The first main systematic question is whether human dignity shall be understood as an (1) unchangeable, essential inner worth of men or as (2) a contingent property like a) status/rank/office, b) behavior, c) esthetic expression, which leads at best to an intersubjective and external understanding of the concept.

\section{Criticism of reductionist contingent or intersubjective conceptions}

Contingent and/or intersubjective interpretations of human dignity reduce its significance in comparison to our highest-ranking interests such as life, health, mental and physical integrity. Such interpretations turn human dignity into one interest among others that can be delimited. This shortcoming holds for the view that human dignity is constituted by the recognition of others ${ }^{29}$ or consists in the external representation of self-respect ${ }^{30}$ and, hence, leads to the demand of non-degrading and respectful treatment by others promoting self-esteem. Nobody will deny that we have a legitimate interest to be recognized by others and to be treated with respect. However, identifying this interest, high ranking as it may be, with human dignity is problematic for three reasons: First, certain behavior can be disrespectful without violating human dignity. If somebody sneaks something from someone else's plate we would consider this as disrespectful and in certain cases even degrading. Yet, we would not consider this to be a violation of that person's dignity. Also, if somebody makes disparaging remarks about an absent third person we would consider this behavior as disrespectful, however, not as affecting that person's human dignity. Second, such a contingent and intersubjective view of human dignity has difficulties in explaining human dignity as pertaining to certain stages in life or certain forms of life, e. g. comatose persons and newborn children. These people have no present need for recognition or respect. Third, such a contingent or inter-subjective interpretation of human dignity contradicts our

29 Hasso Hofmann, Die versprochene Menschenwürde; Peter Baumann, 'Menschenwürde und das Bedürfnis nach Respekt', in: Ralf Stoecker (ed.), Menschenwürde. Annäherung an einen Begriff, Wien 2003, pp. 19-34, p. 26-29.

30 Cf. Avishai Margalit, The Decent Society, Cambridge 1986, pp. 51 f.; Julian Nida-Rümelin, Über menschliche Freiheit Stuttgart 2005, pp. 131 ff. 
general view about the status of dignity in the structure of different interests. On the one hand we believe that the value of human dignity is at least on the same level with life, health, mental and physical integrity (which does not say whether they can be balanced against each other). On the other hand we see that in all recent constitutions or human rights systems, human dignity is either set above or at least beside these most important interests of people. ${ }^{31}$ Therefore, one has to conclude that human dignity cannot be interpreted as contingent or inter-subjective but needs to be interpreted as being necessary and essential. It is at least on par with our most important interests such as life and bodily integrity.

According to another view, ${ }^{32}$ human dignity manifests itself in a group of indispensable rights. These indispensable rights include first the right to have the goods necessary for biological existence, second the right to be free from grievous and constant pain, third the right to a minimum of general freedom, and fourth the right to a minimum of self-respect. It goes without saying that these interests or rights are essential and need to be considered. However, it is questionable why only these rights should be assembled under the label "human dignity". This compilation does not meet the common and at the same time specific aspect of human dignity. ${ }^{33}$

It is however correct that a violation of human dignity is equivalent to a special humiliation and degradation. ${ }^{34}$ Human dignity implies a right not to be degraded. But what does this mean? Somebody is degraded if he cannot respect himself. The dignity of a person exists in his self-respect. At first sight this appears to be clear. However, this characterization is still insufficient. Self-respect is nothing else than a form of selfassessment. However, self-assessment can refer to a variety of things. Somebody can for example lose his self-respect if he does not pass an exam or if he is not as successful at a sport as he wishes. However, in these cases we would not say that his human dignity was violated. Therefore, degradation and humiliation must be directed at a certain central quality of the human being, which is an essential and indispensable part of his self-respect.

\section{Human dignity as being a master of one's own interests and concerns}

The answer to the question about human dignity should start from the basic ethical insight of normative individualism. Accordingly, individuals have to be the ultimate point of reference of ethical justification. ${ }^{35}$ If only individuals can be the ultimate ethi-

31 Cf. Art. 1 I of the German Basic Law: "Human dignity shall be inviolable." UN-Charter; EUHuman Rights Charter.

32 Dieter Birnbacher, 'Ambiguities in the Concept of Menschenwürde', in: Kurt Bayertz (ed.), Sanctity of Life and Human Dignity, Dordrecht/Boston/London 1996, pp. 107-121, p. $110 \mathrm{ff}$.

33 For a criticism see Philipp Balzer/Klaus P. Rippe/Peter Schaber, Menschenwürde vs. Würde der Kreatur: Begriffsbestimmung, Gentechnik, Ethikkommissionen, p. 27.

34 Philipp Balzer/Klaus P. Rippe/Peter Schaber, Menschenwürde vs. Würde der Kreatur: Begriffsbestimmung, Gentechnik, Ethikkommissionen, p. 29.

35 Dietmar von der Pfordten, Normative Ethil Berlin 2010, pp. 22 ff. 
cally authority and if they can principally decide autonomously about justifiable qualities, then the more concrete generalized interests such as mental and bodily integrity do not necessarily exhaust the amount of possible interests. The first and foremost interest is instead the second order wish or interest to have primary interests (which can be either, aims, wishes, needs or strivings). This second order wish is necessary for humans and an internal, not external, one.

The key to the understanding of necessary human dignity is found in an important insight: There is a basic difference between the four morally relevant qualities - aims, wishes, needs and strivings. Strivings and needs cannot be directed at other strivings, needs, wishes or aims. Hence, there are no strivings after strivings and needs after strivings or needs. But there are second order wishes and aims with regard to first order strivings, needs, wishes and aims. Therefore, we can develop the wish to feel the striving to do more sports or the wish to listen to nice music. We can also develop the aim to reduce our need for sleep, to limit our strivings for sweets and to set ourselves more ambitious ecological aims. In contrast to needs and strivings, wishes and aims can be iterated, i.e. they are possible second order qualities with regard to other morally relevant qualities. The reason is perhaps that only wishes and aims are necessarily intentional while this is questionable or contingent in the case of strivings. Only because wishes and aims are intentional, they can refer to other morally relevant qualities. Intentionality is in these cases not only representational but evaluative. Because of our wishes and aims we do not only have the ability to represent morally relevant qualities but also to evaluate them. In this way we can establish our own, subjective order among our morally relevant qualities. We are, for instance, able to super-ordinate the aim to finish a letter over the need to eat something.

Human dignity hence means necessary and internal self-determination and openness of decisions, i.e. of wishes and aims, concerning one's own interests and their importance. ${ }^{36}$ An essential part of our self-understanding and of our self-respect is based on this self-determination and openness of our decisions over our aims, wishes, needs, and strivings. The need for recognition of this kind of self-understanding and self-respect is then only a secondary result of human dignity, not its basis.

This interpretation of human dignity as necessary and internal self-determination of one's own interests fits very well to the frequently found identification of human dignity with a ban of total instrumentalization of others as expressed in Kant's second formula of the categorical imperative (it can however not be based on Kant's writings at the time of the Groundwork of Metaphysics of Morals $\left.{ }^{37}\right) .{ }^{38}$ When asking what it can

36 Harry Frankfurt, 'Freedom of the Will and the Concept of a Person', in: id., The Importance Of What We Care About, Cambridge 1988, pp. 11-25, argues that for the concept of a person second-ordervolitions are decisive. These refer to first order motivational reasons.

37 See above and Dietmar von der Pfordten, Zur Würde des Menschen bei Kant.

38 Immanuel Kant, Foundations of the Metaphysics of Morals, p. 429: “Act in such a way that you treat humanity, whether in your own person or in the person of any other, always at the same time as an end and never merely as a means to an end." 8 
mean to treat someone only as a means the answer cannot merely be: having a single ethically relevant quality disregarded, i.e. a first order interest. In contrast, negating actual or potential wishes and aims concerning one's own interests - i.e. negating second order ethical qualities - implies disregarding all first order interests at the same time as well. For if someone cannot even decide about his wishes and aims with regard to his own interests, then all first order interests are also devaluated as they are not genuine. Someone who negates second order interests also negates all first order interests even if he does not affect every first order single interest directly and independently. In this way it can be explained how a person can be used only as a means.

Conceiving human dignity as self-determination of one's interests can also explain why the notion of human dignity as a point of view on morality and law appears much later in constitutions and human rights declarations than the protection of first order interests such as life, bodily integrity, freedom and property. As it is the case with all meta-phenomena, reflecting on self-determination of one's own interests is an abstract activity that requires knowledge and protection of primary interests in the first place, such as life, bodily integrity, freedom and property.

Dignity conceived as the necessary and internal ability of human (or other rational) beings to reasonable evaluate on a meta-level one's own aims, wishes, needs, and strivings is the indispensable basis for self-respect, which in turn is the necessary ability of being self-contained and having internal independence. However, this ability is not just the ability to act morally as first order needs, wishes, and aims need not necessarily be directed at others but can also relate only to the agent himself. Nevertheless, it is a necessary condition to act morally because every genuine moral action requires a restriction of one's desires and appetite/drives on an evaluative meta-level.

Defining dignity as ability to assess one's own and others' wishes and interests on a meta-level has the advantage that it does not require strong metaphysical or religious premises. It can also be accepted by metaphysical skeptics and agnostics. However, Christians or other believers may interpret dignity in a religious way. An essential aspect of man being created in God's image would then consist in the ability of human beings to reflect on a meta-level one's own and others' interests.

\section{Concrete dangers: forcible tube feeding, lie detectors, torture}

Defining necessary, internal dignity of a human being as his actual or at least potential ability to reasonable - or at least potentially reasonable - draw reference to his own or others' first order needs, wishes and aims can help to explain concrete dangers for dignity, such as forcible tube feeding, the use of lie detectors and torture.

If prisoners decide to go on hunger strike, they have assessed their first order needs and wishes in a highly unusual way. They have subordinated their highest need of absorbing food for life preservation, which usually trumps all the other needs, to the secondary wish for political or humanitarian protest. This is an act that strikingly demonstrates the ability to relativize one's first order needs and wishes on a second, higher level. It is thus an act that manifests the dignity and internal independence of prisoners in an eminent way Forcible tube feeding suppresses this exercise of independence and 
manifestation of dignity of prisoners and therefore violates their human dignity - at least as long as the prisoners are conscious. If they lose their consciousness, tube feeding does not violate their dignity as it is strictly speaking no longer forced. However, the wish not to be tube fed even in case of unconsciousness needs to be heeded as well.

Using a lie detector works in a comparable way. If defendants lie, they evaluate their own interests and the interests of the prosecuting body on a meta-level. They decide against cooperating with the prosecuting body and accept the risk of being proven untruthful. The possibility of second order assessment and with it the exercise of the human dignity is barred by using lie detectors. Therefore, using them or similar means like psychiatric drugs violates human dignity.

Why is torture a violation of human dignity? Inflicting pain without approval as well as the purpose of breaking someone's will contradicts important needs, wishes, and aims of the affected person and is therefore to be evaluated as negative. However, there can be certain situations in which some forms of negative effects on individuals are justified, such as a conviction to imprisonment because of a criminal offence (inflicting pain) or usage of force by the police to avert dangers (breaking the will). The characteristic aspect of torture lies in the purposive connection of both negative evaluated effects, thus in the connection of the instrument of inflicting physical and mental pain with the aim of breaking the will. Thus, physical or mental pain is afflicted with the very aim to break the second order will. Due to the pain, the body or the psyche of the tormented person does not express, as it is usually the case, the person's own will but virtually the foreign will of the torturer.

Thereby, torture sets the will of the tormented person not to reveal anything in destructive opposition to the person's own body or his own psyche, which makes the pain intolerable for him and which forces the confession. The natural unity of the human being, of will and body or psyche is torn apart. The tormented person experiences that his natural unity as a free, self-determined being and as a sensitive body and soul is denied. The natural ability to decide through wishes and aims over one's physical strivings and needs is hence eliminated.

\section{Borderline cases}

One may ask at this point whether, according to this definition, embryos, babies, and comatose persons have necessary, internal dignity. If one conceives of human dignity in the narrow way, as explained above, one cannot hold for these persons that an existing ability to assess aims, wishes, needs and strivings at a second order is violated. The interests of these persons are to be ethically considered, such as their interest to continue to live or their interest to be free of pain. However, they cannot be violated in their existing second order self-determination. Yet, one has to take into account preeffects and after-effects of abilities on the second order. In the same way as actions that will damage somebody only in the future are already morally wrong in the present, the future actualization of the ability to assess on a second level is already vulnerable in embryos and babies, for instance if they are cloned or selected. In the same way necessary, internal dignity of comatose persons continues to exist as a claim on others as the 
now comatose had directed their self-determination upon a future up to the end of their lives and, in some aspects, even post mortem before falling into coma. Moreover, one can never be certain that a person does not gain the ability to exercise his selfdetermination about his interests again. Therefore, one has to hold that human beings from the beginning of life, that is already before birth, with the fusion of ovum and spermatozoon with regard to some aspects, up to the end of life and, with regard to some other aspects, even after life, have necessary, internal dignity. 